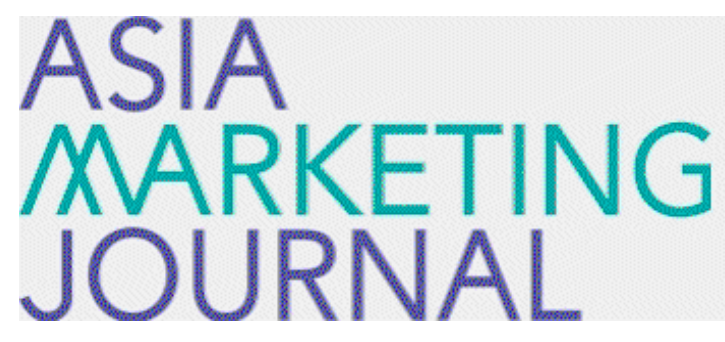

ASIA MARKETING JOURNAL

Volume 1 | Issue 3

Article 2

6-1-1999

\title{
The Influence of the Consumption Ritualization on Buying Behaviors
}

Cheol Park

Follow this and additional works at: https://amj.kma.re.kr/journal

Part of the Marketing Commons

\section{Recommended Citation}

Park, Cheol (1999) "The Influence of the Consumption Ritualization on Buying Behaviors," Asia Marketing Journal: Vol. 1 : Iss. 3 , Article 2.

Available at: https://doi.org/10.53728/2765-6500.1016

This Article is brought to you for free and open access by Asia Marketing Journal. It has been accepted for inclusion in Asia Marketing Journal by an authorized editor of Asia Marketing Journal. 


\title{
The Influence of the Consumption Ritualization on Buying Behaviors
}

\author{
Cheol Park \\ (Department of Distribution Management, DongEui Univ. \\ cpark@hyomin.dongeui.ac.kr )
}

Recently, consumer researchers have been interested in consumption ritual that expressed condensedly the consumption system in a culture. From various disciplines this study examined the 'ritual' and 'ritualized behavior' which are unique to human beings and analyzed the relation of ritualization of consumption experience and buying behavior. According to the degree of ritualization, consumers were categorized into four types - ritualized, habitualized, involved, and non-ritualized consumers. In the empirical study, the relation between ritualization of "dressing-up (i.e. to put on the clothing with the intention of wearing displaying them publicity)" and buying behaviors related to clothing was explored through in-depth interviews and a questionnaire survey with 434 married Korean women. Through statistical analysis, research questions were identified in an empirical study: as the consumption experience becomes more ritualized, the purchasing frequency, ongoing involvement, brand loyalty, and opinion leadership will increase as part of clothing buying behavior. Herein, the implications of the study and further research issues are discussed.

\footnotetext{
* The Author wishes to acknowledge the financial support of the Korea Research Foundation made in the program year of 1997.
} 
Recently, consumer researchers have begun to focus their attention on the construct of ritual that concisely expresses the consumption system in a culture (Rook and Levy 1983; Sherry 1983; Kehert-Ward, Johnson, and Louie 1985; Rook 1985; Solomon and Anand 1985; McCraken 1986, 1988; Pollay 1987; Belk, et al. 1988; Belk 1990; Tetreault and Kleine III 1990; Belk and Coon 1991; Wallendorf and Arnould 1991; Schouten 1991; Adelman 1992; Levinson, et. al. 1992; Ozanne 1992; Holt 1992; Otnes and Lowrey 1993; McAlexander et. al. 1993; Gainer 1995; Gentry et. al. 1995; Otnes, Nelson, and McGrath 1995; Ruth 1995 ; Schmidt 1995; Otnes and Scott 1996; Goodwin and Gentry 1997; Noble and Walker 1997; Park 1997).

Numerous rites of passage occur in a human lifetime (Van Gennep 1908), and our lives are full of ritualized behaviors (Rook 1985). Researchers in consumer studies have been interested in the types of consumption associated with ritual occasions such as Christmas (e.g. Belk 1989; Sherry and McGrath 1989), Thanksgiving (Wallendorf and Arnould 1991), Halloween (Belk 1990; Levinson et al. 1992), and rites of passage (Ozanne 1992; Escalas 1993; Fischer and Gainer 1993; McAlexander et. al. 1993; Noble and Walker 1997; Park 1997). Rook (1985) noted that these occasions are worthy of study because consumers often devote much time and effort to the purchasing of goods and services that enable them to participate fully in these events. Tetreault and Kleine III (1990) suggested that the power of ritual as an analytical category for consumer research is twofold. First, it describes a system in which consumption behavior is an important component and thus provides an analytically tractable microcosm within which the consumption systems of the larger culture are condensed and brought into relief. Second, ritual emphasizes the integrated nature of psychological and social structural phenomena. Ritualized behavior leads to ritualized consumption that is patternized and symbolic. For example, there are special goods to be consumed in festival or folk rituals like greeting cards on Christmas, chocolates on Valentine, turkeys on Thanksgiving, etc. If a consumer behavior is ritualized, it would be easy to 
predict and explain. Therefore the more ritualized a consumption for certain goods, the lesser the marketing efforts of the companies. The previous researches on ritual in consumer behavior are divided into two groups; research related to ritualized situations and research related to ritualized behaviors. Rites of passage (Solomon and Anand 1985; Belk and Coon 1991; Bernard, et. al. 1991; Schouten 1991; Ozanne 1992b; Hill 1992; Otnes and Lowrey 1993; Escalas 1993; Fischer and Gainer 1993; McAlexander et. al. 1993; Gentry et. al. 1995; Goodwin and Gentry 1997; Park 1997), festival rituals (Pollay 1987; Belk 1990; Wallendorf and Arnould 1991; Levinson, et. al. 1992), and ritual situation effects (Kehert-Ward, Johnson, and Louie 1985; Kehret-Ward and Goldin 1988) represent research on ritualized situations. The research related to the ritualized behavior focused upon grooming, possession, and aesthetic rituals that have ritual dimensions of individual consumption (Rook and Levy 1983; Sanders 1985; Belk 1988; Belk, et al. 1988; Adelman 1992; Mehta and Belk 1991; Gainer 1995; Tompson and Hirschman 1995).

Previous researches adapted case studies, ethnography, in-depth interviews, projective techniques, and quantitative methods. They were, however, exploratory, conceptual, and descriptive. They were apt to pursue purely theoretic knowledge rather than applicable knowledge to the marketing strategies. The purpose of the research is to measure the degree of ritualization toward certain consumption experiences and to explore the relationships between consumer ritualization and buying behavior. The present study chose "dressing-up" and clothing as its object of empirical exploration.

\section{RITUALIZATION OF CONSUMPTION EXPERIENCES}

Consumption experiences are defined as "the whole process that consumers could experience using products and services which the company offered (Holbrook and Hirschman 1982; Hirschman and Holbrook 1982; 
Holbrook et al. 1984; Hirschman 1986; Havlena and Holbrook 1986; Marks et al. 1988; Lofman 1991)." Ritualization of consumption experience means that a consumption experience becomes a ritual for a consumer. It means, in other words, consumer behaviors in the consumption experience become more typical, repetitive, procedural, symbolized, formalized, and immersive. As well there are ritual scripts, roles, audiences, and artifacts in the consumption experience. For example, a ritualized consumer in grooming(consumption experience) has a script(grooming process and method), various grooming artifacts, audiences(others who pay attention to his grooming performance), and performs various roles in the grooming process. In proportion to the ritualization, a consumer is going to symbolize his consumption experience to communicate meanings. Therefore, ritualization of consumption experience may be defined as follows;

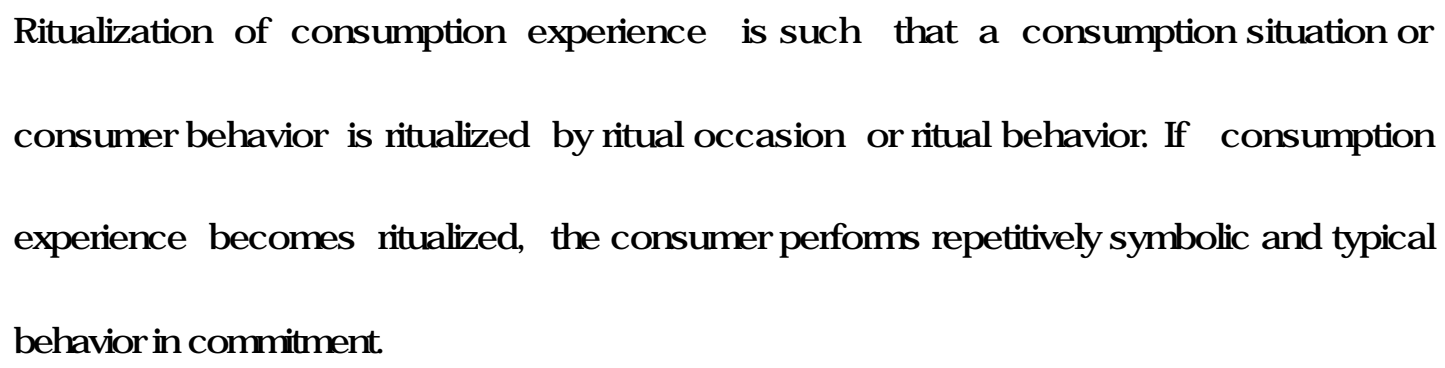

In regards to inner attitudes and outer behaviors, the degree of the ritualization of consumption experience can be divided into external and internal ritualization. External ritualization is a degree of ritualization expressed in appearances which contains procedurality, typicality, and repetitiveness of behavior(Mead 1956; Rook 1985; Tetreault and Kleine III 1990). Internal ritualization is a degree of ritualization formed inside which contains sincereness, symbolism, immersion, and formality(Durkheim 1912; Bird 1980; Moore and Myeroff 1977; La Fontain 1985; Rook 1985; Tetreaut and Klein III 1990). 


\section{External Aspects of Ritualization}

Procedurality Ritual consists of an episodic string of events (Rook), and ritual behavior proceeds in fixed orders(Mead 1956; Rook 1985). This characteristic of ritual behavior may be called "procedurality." Typicality Ritual behavior has a set of patterns which are expressed in formal scripts, formed in norms by tacit consent, or internalized individually(Durkheim 1912; Bird 1980; Moore and Myeroff 1977; La Fontain 1985; Rook 1985; Tetreault and Kleine III 1990).

Repetitiveness Ritual behavior is repeated at intervals but it doesn't mean mechanical and instinctive repetition(Mead 1956; Moore and Myeroff 1977; Rook 1985). In spite of repetition, ritual behavior creates new emotions and meaning each time.

\section{Internal Aspects of Ritualization}

Sincereness Ritual behavior is performed sincerely in its own way. So, it can be distinguished from an episodic event or happening. Sincereness of ritual behavior means that it is proceeded by a certain intention and purpose and accompanies internal intensiveness (Bird 1980; Moore and Myeroff 1977; Rook 1985).

Symbolism Ritual behavior characteristically communicates and expresses meanings or images (Tetreault and Kleine III 1990; Kertzer 1988; Munn 1973; Turner 1967). According to the time, the meaning of ritual is repeated, structuralized, and communicated using artifacts that are dramatic and complex.

Immersion Those who perform the rituals are apt to be involved and absorbed in them (Rook 1985). Ritual performances require intensive immersion. 
Formality Ritual behavior is ceremonious and characterized by an established form (Rook 1985). The more conscious of the audiences' responses the ritual performer is, the more formal the ritual behavior will be.

These two dimensions of ritualization in consumption experience allow us to divide consumer behavior into four types - ritualized behavior, habitualized behavior, high-involved behavior, and non-ritualized behavior according to the degree of ritualization (see the figure 1). Ritualized behavior can be classified as high ritualization internal and external (e.g. drinking wine at the Mass), habitualized behavior in high external ritualization but low internal ritualization (e.g drinking behaviors of alcoholics), high-involved behavior in low external ritualization but high internal ritualization (e.g. high involvement on wine and drinking without actual drinking owing to health, money, and situations), and non-ritualized behavior can be classified in low ritualization both external and internal(e.g. non-drinking of alcohol).

Figure 1

\section{BEHAVIOR CLASSIFICATION BY DEGREE OF RITUALIZATION}

External Aspects of Ritualization

High Low

\begin{tabular}{ll|l|l|}
\begin{tabular}{lll} 
Internal \\
Aspects of \\
\cline { 2 - 3 } Ritualization
\end{tabular} & Ritualized Behavior & $\begin{array}{l}\text { High Involvement } \\
\text { Behavior }\end{array}$ \\
\cline { 2 - 3 } & Low & $\begin{array}{c}\text { Habitualized } \\
\text { Behavior }\end{array}$ & $\begin{array}{c}\text { Non-ritualized } \\
\text { Behavior }\end{array}$ \\
\cline { 3 - 3 } & &
\end{tabular}

\section{RITUALIZATION OF DRESSING-UP AND CLOTHING BUYING BEHAVIOR}

The "dressing-up" of Korean married women was chosen as the research area of consumption ritualization in empirical study. "Dressing-up" is to put on the clothing with the intention of wearing displaying them publicity. It 
is a typical body grooming ritual with clothing. It can be called a ritualistic consumption experience related to clothing consumption (Holman 1980; Solomon and Anand 1985) because clothing can function as ritual artifacts in various situations and communicate symbolic meanings and images with others. Ritualization of "dressingup" may be related to consumer behaviors in clothing consumption.

\section{In-Depth Interviews}

A phenomenological approach is recommended for the emerging field of ritual study to clarify issues, generated propositions, understand consumers' experiences, and guide future research efforts (Tetreault and Kleine 1990). In-depth interviews were used to explore the research propositions in this study because validity is best assessed using multiple methodologies (Calder 1977). The findings that were gathered through in-depth interviews helped in the design of the survey and its items.

Procedures During the summer of 1996, three separate interview sessions with seven housewives and four working women were performed in Korean major city. Participants ranged in age from early thirties to mid forties. Two interview sessions were held with two group of housewives, and the other with working women. All participants were selected conveniently but appropriated to the research topic. They were offered special dinners as rewards for participating.

Findings Through content analysis of the in-depth interviews, ritualization of dressing-up and its relationship with clothing buying behaviors were identified. Respondents were classified into several groups. Some unique observations were as follows. Two housewives considered dressing-up as important parts of their lives. They reported, "I am nervous and want to come back home as fast as possible when I feel my dress is not fit for the situation." They put on clothing like actresses on the stage and their "dressing up" was a ritualized life 
performance. They possessed more clothing than the others interviewed and had high ongoing involvement and brand loyalty. Sometimes they used to buy clothing impulsively and held great opinion leadership in regards to clothing. One working woman dressed herself very automatically. She said "I dress up every day but it is just habitualized and patternized behavior without any deep meaning related to grooming." Buying clothing for her was a kind of task that it was better to finish as faster as she could. One housewife was interested in clothing and grooming but she rarely had time to go out on dressing-up. She said, "I always feel pressured to put on clothing when I go out because I rarely go out, and I am unskillful in dressing-up." She had less clothing brand loyalty, opinion leadership, and purchasing frequency.

\section{Emerging Research Questions}

From in-depth interviews, several exploratory research questions were developed in order to examine the ritualization of dressing-up and clothing buying behavior. Based on in-depth interviews, purchasing frequency, ongoing involvement, brand loyalty, and opinion leadership were chosen as clothing buying behavior variables.

Purchasing Frequency The higher the degree of ritualization of consumption experience a consumer has, the more frequent they will purchase specific products and services relating to the consumption experience. As ritualized behavior is repetitive, it is the same with the purchasing of products needed in the ritual (Rook 1985). So, the purchasing frequency increases. Purchasing frequency of clothing is more related to a consumer's outer behavior than inner attitude. The purchasing frequency of clothing is thus more related to the external ritualization of dressing-up than it is to internal ritualization.

Ongoing Involvement Ongoing involvement is relatively long-term importance or the level of interest towards a products (Bloch and Richins 1983). If a behavior becomes ritualized, the individual value of products which are 
needed in performing the behavior becomes higher (Bloch, Sherrell, and Ridgway 1986). Therefore, the ongoing involvement of the products would also be higher. Ongoing clothing

involvement would be more related to a consumer's inner attitude than to outer behavior. So, ongoing clothing involvement is more related to the internal ritualization of dressing-up than to external ritualization.

Brand loyalty Brand loyalty represents a favorable attitude toward a brand resulting in its consistent purchase over time (Assael 1992, 87-90). However, inertia - that is, the repeat purchasing of a brand with commitmentrepresents habitual purchasing with a low level of involvement. In this case, the consumer has no strong opinions or feelings about the brand(Assael 1992). Consumer symbolism approaches insist that consumers repetitively purchase a brand which has congruity with her self-image and social role (Rook 1985). As ritual behavior is extensively scripted and highly redundant (Rook 1984), the higher the ritualization of the consumption experience is the higher the brand loyalty will be. Brand loyalty with clothing is more related to a consumer's outer behavior rather than inner attitude. So, brand loyalty with clothing is more related to the external ritualization of dressing-up than it is to an internal ritualization.

Opinion Leadership Opinion leadership is influential in creating a consensus or public opinion about a specific product or product category. According to the repetition of behaviors through the ritualization of consumption experience, one can accumulate knowledge about the consumption experience and have opinion leadership in the purchasing of products that are needed in performing the ritual(Riecken and Yavas 1983; Childers 1986; Goldsmith and Desbord 1991). Ritual theories suggest that ritual experts influence and dominate ordinary people (Durkheim 1912). We can assume that the higher the degree of ritualization of dressing-up a consumer has, the higher opinion leadership of clothing she/he has. Opinion leadership in regards to clothing is more related to a 
consumer's outer behavior rather than to inner attitude. So, opinion leadership of clothing is more related to the external ritualization of dressing-up rather than to internal ritualization.

Research Question 1: Are there any differences of clothing purchase frequency, ongoing involvement, brand loyalty, and opinion leadership among the ritualized, habitualized, high involved, and non-ritualized groups on dressing-up?

Research Question 2: How the internal and external ritualizations of dessing up associate with clothing purchase frequency, ongoing involvement, brand loyalty, and opinion leadership?

\section{METHOD}

\section{Samples and Procedures}

The subjects of the empirical study were Korean married women. A survey using the interview was performed during October 1996. Thirty interviewers who had attended a marketing research course at a university in Korea were recruited to do the survey. Respondent were selected through convenience sampling. Interviewers met respondents at their residences, beauty salons, banks, ongoing education centers, and churches, etc. Response rate was $86.8 \%$, and 434 questionnaires were completed through the survey. Six point two percent of the sample members were in their twenties, $26.8 \%$ were in their thirties, $44.8 \%$ were in their forties, and $22.2 \%$ were over fifty. The sample consisted of $72.3 \%$ full-time housewives and $27.2 \%$ working women. The mean number of their children was 2.34 and the mean monthly family income was about $\$ 2,744$. 


\section{Measurements}

Measurement scale for consumer ritualization was developed based on Churchill (1979) by an author. A measurement of ritualization of dressing-up included a seven-point Likert-type scale from "strongly agree" (7) to "strongly disagree" (1). All items in the questionnaire used a similar seven-point Likert-type scale. After testing reliability and validity, a final seven items were chosen(see Table 1). A measurement of clothing ongoing involvement items based on Bloch, Sherrel, \& Ridgway (1986), included 4 questions, clothing brand loyalty items based on Olsen (1993),included 3 questions, and clothing opinion leadership items based on Goldsmith \& Desborde (1991), included 4 questions. Clothing buying frequency was measured by the open-ended question; How many times did you buy clothing per year?

\section{RESULTS}

\section{Reliability and Validity of Measurements}

The factor structure of ritualization of dressing-up consisted of two aspects, internal and external ritualization(see Table 1). The reliability coefficient for the external ritualization factor with 3 measurement items was .7496, the internal ritualization with 4 measurement items was .8143 , ongoing clothing involvement was .8576 , brand loyalty with 3 items was .7598, and opinion leadership of cloths with 3 items was .8520 .

TABLE 1

RITUALIZATION OF DRESSING-UP SCALE AND ITEM RELIABILITY

Ritualization Scale

Cronbach Alpha

External 1. I tend to put clothing on myself as patternized procedures when I go out. $\quad .7496$

Ritualization. 2. I have regular types or styles of dressing -up according

to the situation when I go out

3. I go out regularly with dressing-up.

1999. 6

The Influence of Consumption Ritualization 22 
Internal 4. When I am dressing up for going out I think it over sincerely

Ritualization in regards to my appearance.

5. I try to express my image through dressing-up when I go out.

6. I tend to make efforts to choose clothing when I go out.

7. I try to put on clothing to fit the situations I will encounter.

TABLE 2

PARAMETER ESTIMATION OF INTERNAL AND EXTERNAL RITUALIZATION

\begin{tabular}{cccc}
\hline \hline Parameters & Standardized Estimator & Standard Error & T-value \\
\hline$\lambda \times 11$ & .675 & & \\
$\lambda \times 21$ & .712 & .000 & - \\
$\lambda \times 31$ & .689 & .076 & 13.9 \\
$\lambda \times 42$ & .671 & .103 & 9.9 \\
$\lambda \times 52$ & .769 & .000 & - \\
$\lambda \times 62$ & .777 & .096 & 12.0 \\
$\lambda \times 72$ & .749 & .098 & 12.0 \\
$\phi 21$ & .867 & .098 & 11.5 \\
\end{tabular}

A maximum-likelihood confirmatory factor analysis (see Table 2) was performed on the covariance matrix to identify the validity for the measurement structure of ritualization (Gerbing and Anderson 1988). $\alpha$ coefficients connecting constructs to measurement items were statistically significant. Overall model fit of the confirmatory factor analysis model proved excellent, Chi-square $=10.55$ (d.f.=11), $\mathrm{p}=.48$, AGFI $=0.98$, and $\mathrm{RMR}=0.016$. Table 2 presents the parameter estimates for the measurement model.

\section{Differences of Clothing Buying Behaviors According to ritualization}


Samples were divided into four groups - ritualized, habitualized, involved, and non-ritualized groups by the mean value of internal $(\mathrm{m}=5.29)$ and external $(\mathrm{m}=5.05)$ ritualization of dressing-up (see Table 3$)$.

TABLE 3

IDENTIFYING FOUR GROUPS ACCORDING TO RITUALIZATION OF DRESSING-UP

\begin{tabular}{lccccc}
\hline \hline & $\begin{array}{c}\text { Ritualized } \\
(\mathrm{n}=147)\end{array}$ & $\begin{array}{c}\text { High-Involved } \\
(\mathrm{n}=64)\end{array}$ & $\begin{array}{c}\text { Habitualized } \\
(\mathrm{n}=71)\end{array}$ & $\begin{array}{c}\text { Non-ritualized } \\
(\mathrm{n}=149)\end{array}$ & $\mathrm{F}$ \\
\hline External & 5.88 & 4.53 & 5.59 & 4.24 & $265.9^{* * *}$ \\
Ritualization & $\mathrm{A}^{*}$ & $\mathrm{~B}$ & $\mathrm{~A}$ & $\mathrm{~B}$ & \\
Internal & 6.04 & 5.85 & 4.84 & 4.45 & $283.6^{* * *}$ \\
Ritualization & $\mathrm{A}$ & $\mathrm{A}$ & $\mathrm{B}$ & $\mathrm{B}$ & \\
\hline
\end{tabular}

Sheffe Test Result(Different Alphabet means no significant differences in 5\% confidence level)

$* * * \mathrm{p}<.001$

TABLE 4

MEAN DIFFERENCES OF CLOTHING BUYING BEHAVIORS AMONG IDENTIFIED FOUR GROUPS

\begin{tabular}{lccccc}
\hline & $\begin{array}{c}\text { Ritualized } \\
(\mathrm{n}=147)\end{array}$ & $\begin{array}{c}\text { High-Involved } \\
(\mathrm{n}=64)\end{array}$ & $\begin{array}{c}\text { Habitualized } \\
(\mathrm{n}=71)\end{array}$ & $\begin{array}{c}\text { Non-ritualized } \\
(\mathrm{n}=149)\end{array}$ & $\mathrm{F}$ \\
\hline Clothing Purchase & 4.36 & 3.97 & 4.21 & 3.82 & $5.28^{* * *}$ \\
Frequency & $\mathrm{A} *$ & $\mathrm{~B}$ & $\mathrm{~A}$ & $\mathrm{~B}$ & \\
Clothing Ongoing & 4.94 & 4.48 & 4.03 & 3.78 & $34.0^{* * *}$ \\
Involvement & $\mathrm{A}$ & $\mathrm{B}$ & $\mathrm{BC}$ & $\mathrm{C}$ & \\
Clothing Brand & 4.05 & 3.48 & 3.57 & 3.36 & $6.76^{* * *}$ \\
Loyalty & $\mathrm{A}$ & $\mathrm{AB}$ & $\mathrm{AB}$ & $\mathrm{B}$ & \\
Clothing Opinion & 4.44 & 4.01 & 4.14 & 3.50 & $18.52^{* * *}$ \\
Leadership & $\mathrm{A}$ & $\mathrm{AB}$ & $\mathrm{A}$ & $\mathrm{B}$ & \\
\hline
\end{tabular}

Sheffe Test Result(Different Alphabet means no significant differences in 5\% confidence level)

$* * \mathrm{p}<.01, * * * \mathrm{p}<.001$ 
To examine research question 1, ANOVA procedures and Sheffe test were performed. The dependent variables were purchase frequency, ongoing involvement, brand loyalty, and opinion leadership of clothing. Independent variable was ritualization of dressing-up (four groups). Results are summarized in Table 4. There were significant differences of purchase frequency, ongoing involvement, brand loyalty, and opinion leadership of clothing among four groups. Generally, the results shows that the more ritualized the dressing-up is, the higher the purchase frequency, ongoing involvement, brand loyalty, and opinion leadership of clothing are.

\section{Internal and External Ritualization and Clothing Buying Behavior}

To identify the relationship between external/internal ritualization of dressing-up and clothing buying behaviors, the structural equation parameters were estimated using LISREL (Table 5). The purpose of using LISREL is not to identify the causal relationships among variables, but to explore the simple relationship among variables.

\section{TABLE 5}

THE RELATIONSHIP BETWEEN RITUALIZATION OF DRESSING-UP AND CLOTHING BUYING BEHAVIOR

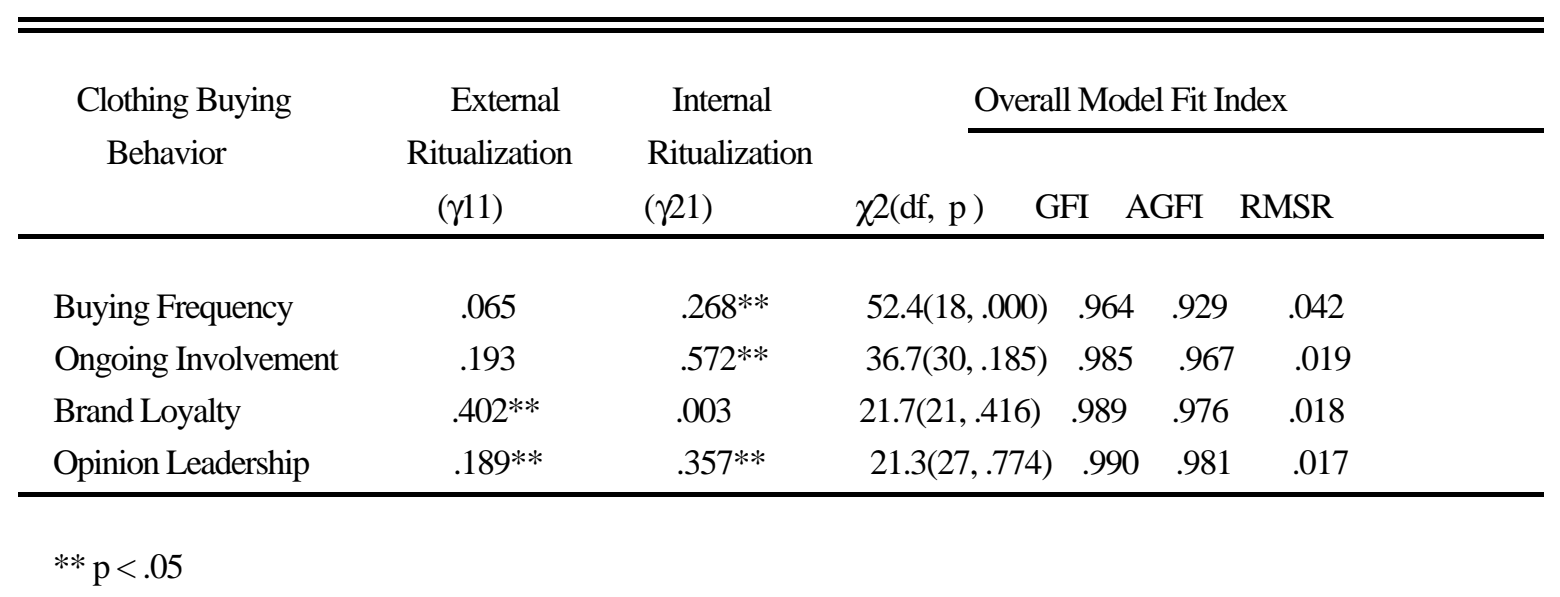


First, as the relationship between the external/internal ritualization of dressing-up, and clothing purchasing frequency was identified, there was a significant path between the internal ritualization of dressingup and clothing purchasing frequency $(\gamma 12=.268, \mathrm{t}=2.65, \mathrm{p}<.05)$, but not between the external ritualization of dressing-up and clothing purchasing frequency $(\gamma 11=.065, \mathrm{t}=0.64)$. Overall model fit of this model proved to be fair, $\chi 2=52.43$ (d.f.=18, $\mathrm{p}=.000$ ), $\mathrm{AGFI}=0.93$, and $\mathrm{RMR}=0.042$. Second, as the relationship between the external/internal ritualization of dressing-up, and ongoing clothing involvement was identified, there was a significant path between the internal ritualization of dressing-up and clothing purchasing frequency $(\gamma 12$ $=.572, \mathrm{t}=3.79, \mathrm{p}<.05)$, but not between the external ritualization of dressing-up and clothing purchasing frequency $(\gamma 11=.193, \mathrm{t}=1.28)$. Overall model fit of this model proved good, $\chi 2=36.73(\mathrm{~d} . \mathrm{f} .=30$, $\mathrm{p}=.185)$, AGFI $=0.97$, and RMR $=0.019$. Third, as the relationship between the external/internal ritualization of dressing-up, and clothing brand loyalty was identified, there was a significant path between the external ritualization of dressing-up and clothing purchasing frequency $(\gamma 11=.402, \mathrm{t}=2.36, \mathrm{p}<.05)$, but not between the internal ritualization of dressing-up and clothing purchasing frequency $(\gamma 12=.004, t=0.02)$. Overall model fit of this model proved good, $\chi 2=21.71$ (d.f. $=21, \mathrm{p}=.416), \mathrm{AGFI}=0.98$, and RMR $=0.018$. Forth, as the relationship between the external/internal ritualization of dressing-up, and opinion leadership of clothing was identified, there were a significant paths between the external ritualization of dressing-up and opinion leadership of clothing $(\gamma 11=.193, \mathrm{t}=2.51, \mathrm{p}<.05)$ as well as between the internal ritualization of dressing-up and opinion leadership of clothing $(\gamma 12=.572, \mathrm{t}=4.32, \mathrm{p}<.05)$. Overall model fit of this model proved good, $\chi 2=$ 21.27 (d.f. $=27, \mathrm{p}=.774), \mathrm{AGFI}=0.98$, and $\mathrm{RMR}=0.017$. 


\section{DISCUSSION AND CONCLUSION}

As results of differences related to clothing buying variables among four groups (the ritualized, the habitualized, the high-involved, and the non-ritualized), we assume that the ritualization of consumption experience may have potentiality in consumer behavior. Ritualization of consumption experience, which adheres to the behavioral variable, might be considered a more useful alternative to explain buying behavior than attitude variables like involvement. The two dimensions of the ritualization of consumption experience imply that the "ritual" perspective would be useful for researching brand loyalty, ongoing involvement, and opinion leadership in consumer behavior as well.

After investigating the relationships between the external/internal ritualization of dressing-up and clothing buying behaviors, it was found that the higher the internal ritualization of dressing-up, the higher the clothing purchasing frequency and ongoing clothing involvement would be while the higher the external ritualization of dressing-up, the higher the clothing brand loyalty would be. Opinion leadership of clothing had positive relationships both with the external and internal ritualization of dressing-up. Clothing brand loyalty and opinion leadership which were directly related to the behavior had positive relationships with the external ritualization of dressing-up. Ongoing clothing involvement which was related to the attitude prior to the behavior had positive relationships with the internal ritualization of dressing-up. However, purchasing frequency of clothing would have a positive relationship with the internal ritualization of dressing-up rather than the external, and clothing brand loyalty having repetitive attributes had a positive relationship with the external ritualization of dressing-up. While the opinion leadership of clothing was higher when consumption experience was ritualized both internally and externally, so opinion leadership might come from consumer's inner attitude as well as outer behavior. 
According to these findings, the internal ritualization has a greater influence on buying behavior than external ritualization. Habitualized consumption experience could not much influence buying behavior when compared with the ritualized consumption experience. Habitualized consumers who ritualize externally might have a tendency to change their buying patterns, so that they might than become ritualized internally.

As consumers perform various rituals and ritualized behaviors, many ritual artifacts including commercial goods are needed for them. If companies develop a deeper understanding of consumer's ritual behavior, they could develop proper ritual products. In order to develop ritual oriented products, companies could focus on not only the existing rituals (traditional rituals, for example rites of passage) but also the emerging ritual (modern rituals, for example leisure activities). Even for service industries, completely new ritual services might be created. In addition ritual oriented products could be developed when the usage behaviors of consumers are better understood in ritual context. As well, promotional messages could become "ritual scripts" which encourage consumption as ritualized experience.

Present research is in the exploratory stage, and this study presents several challenges with respect to theory building and method. Some measurement scales were based on subjective interviews, and convenience sampling makes research objectivity questionable. Ritualization of consumption experience is so wide and abstract a construct that it might be hard to measure by some items. Therefore, a "naturalistic inquiry" ought to be carried out at the same time for deeper study. More buying variables should be examined in order to connect the ritualization of consumption experience to buying behavior.. Unforunately this study could not suggest a causal model including purchasing frequency, ongoing involvement, brand loyalty, and opinion leadership together. There seems to be mediating variables between the ritualization of consumption experience 
and buying behavior. These require identification for developing comprehensive causal models in the future. The contribution of the present work will be made clearer through that effort.

\section{REFERENCES}

Adelman, Mara B. (1992), "Rituals of Adversity and Remembering: The Role of Possessions for Persons and Community Living with AIDS," Advances in Consumer Research, 19, 401-403.

Assael, Henry (1992), Consumer Behavior and Marketing Action, 4th eds., Boston, MA: PWSKENT.

Belk, Russell, Melane Wallendorf, and John F. Sherry, Jr. (1989), "The Sacred and Profane in Consumer Behavior: Theodicy on the Odyssey," Journal of Consumer Research, 16 (June), 1-38.

-- (1990), "Halloween: An Evolving American Consumption Ritual," Advances in Consumer Research, 17, 508-517.

Bird, Frederrick (1980), "The Contemporary Ritual Milieu," in Ray B. Browne, ed., Rituals and Ceremonies in Popular Culture, Bowling Green, $\mathrm{OH}$ : Bowling Green University Popular Press, 19-35.

Bloch, Peter H. and Marsha L. Richins (1983), "A Theoretical Model for the Study of Product importance Perceptions," Journal of Marketing, 47 (Summer), 69-81.

---------, Daniel L. Sherrell, and Nancy M. Ridgway (1986), "Consumer Search: An Extended Framework," Journal of Consumer Research, 13 (June), 119-126.

Browne, Ray B. (1980), Rituals and Ceremonies in Popular Culture, Bowling Green, OH: Bowling Green University Popular Press.

Calder, B. J. (1977), "Focus Groups and Nature of Qualitative Marketing Research, " Journal of Marketing Research, 14 (May), 353-364.

Childers, Terry L. (1986), "Assessment of the Psychometric Properties of an Opinion Leadership Scale," Journal of Marketing Research, 23 (May), 184-188.

Churchill, Jr., Gilbert A. (1979), "A Paradigm for Developing Better Measures of Marketing Constructs," Journal of Marketing Research, 16(February), 64-73. 
Durkheim, Emile (1912), The Elementary Forms of the Religious life, London: Allen and Unwin

Erikson, Erik H. (1963), Childhood and Society (2nd ed.), New York: W.W Norton \& Company.

Escalas, Jennifer Edson (1993), "The Consumption of Insignificant Rituals: A Look at Debutante Balls," Advances in Consumer Research, 20, 709-716.

Firth, Raymond (1956), "Ceremonies for Children and Social Frequency in Tikopia," Oceania, 27, 1255.

Fischer, Eileen and Brenda Gainer (1993), "Baby Showers: A Rite of Passage in Transition," Advances in Consumer Research, 20, 320-324.

Gainer, Brenda (1995), "Ritual and Relationship: Interpersonal Influences on Shared Consumption," Journal of Business Research, 32 (3), 253-260.

Gentry, James W., Patricia F. Kennedy, Catherine Paul, and Ronald P. Hill (1995), "Family Transitions During Grief: Discontinuities in Household Consumption Patterns, "Journal of Business Research, 34, 67-79.

Gerbing, David W. and James C. Anderson (1988), "An Updated Paradigm for Scale Development Incorporating Unidimensionality and Its Assessment, Journal of Marketing Research, 25 (May), 186-192.

Glukman, Max (1965), Politics, Law, and Ritual in Tribal Society, Oxford: Blackwell.

Goldsmith, Ronald E. and Rene Desborde (1991), "A Validity Study of a Measure of Opinion Leadership," Journal of Business Research, 22, 11-19.

Goodwin, Cathy and James W. Gentry (1997), "The Role of Service During Consumer Transitions, " in Research in Consumer Behavior, 8, R.W. Belk ed., Greenwich, CT: JAI Press Inc., 271-291.

Grims, Ronald L. (1985), Research in Ritual Studies: A Programmatic Essay and Bibliography, Metuchen, NJ: The Scarecrow Press.

Holbrook, Morris B. and Elizabeth C. Hirschman (1982), "The Experiential Aspect of Consumer Behavior: Consumer Fantasies, Feelings, and Fun," Journal of Consumer Research, 9 (September), 132-140.

Donald R. Lehmann and John O'Shaughnessy (1986), " Using versus Choosing: The Relationship of the Consumption Experience to Reasons for Purchasing," European Journal of Marketing, 29 (8), 49-62. 
Holman, Rebeca H. (1980), "Apparel as Communication," in Symbolic Consumer Behavior, eds. Elizabeth C. Hirschman and Morris B. Holbrook, Ann Arbor, MI: Association for Consumer Research, 7-15.

Holt, Douglas B. (1992), "Examining the Descriptive Value of "Ritual" in Consumer Behavior: A View from the Field," Advances in Consumer Research, 19, 213-218.

Joreskog, Karl G. and Dag Sorbom (1993), LISREL8 User's Reference Guide, Chicago, IL: Scientific Software International, Inc.

Kehret-Ward, Trudy and Macia W. Johnson and Therese A. Louie (1985), "Improving Recall by Manipulating the Syntax of Consumption Rituals, Advances in Consumer Research, 11, 319-324.

-----------, and Anya Goldin (1988), "Gender and Situational Influences on the Syntex of Consumption Rituals," Advances in Consumer Research, 14, 203.

La Fontain, Jean (1985), Initiation, Harmondsworth, G. B.: Penguin Books.

Leach, Edmund R. (1968a), "Ritual," International Encyclopedia of the Social Science, vol. 13, David L Sills ed., New York: The Macmillan Company and The Free Press, 520-526.

Levinson, Stacey, Stacey Mack, Dan Reinhardt, Helen Suarez, and Grace Yeh (1992), "Halloween as a Consumption Experience," Advances in Consumer Research, 19, 219-228.

Lowrey, Tina M. and Cele Otnes (1994), "Construction of Meaningful Wedding: Differences Between the Prioities of Brides and Grooms," in Gender and Consumer Behavior, ed. J. Costa, Beverly Hills: Sage Publications, 164-183.

McAlexander, James H., John W. Schouten, and Scott D. Roberts (1993), "Consumer Behavior and Divorce, " in Research in Consumer Behavior, 6, J. A. Costa and R.W. Belk eds., Greenwich, CT: JAI Press Inc., 153-184.

McCracken, Grant (1986), "Culture and Consumption: A Theoretical Account of the Structure and Movement of the Cultural Meaning of Consumer Goods," Journal of Consumer Research, 13 (June), 71-84.

Mead, George H. (1956), On Social Psychology, Chicago, IL: University of Chicago Press.

Moore, Sally F. and Barbara G. Myerhoff (1977), Secular Ritual, Amsterdam, The Netherlands: Van Gorcum. 
Noble, Charles H. and Beth A. Walker (1997), "Exploring the Relationships among Liminal Transitions, Symbolic Consumption, and the Extended Self, " Psychology and Marketing, 14(1), 29-47.

Nunnally, Jum C. (1967), Psychometric Theory, New York: McGraw-Hill.

Olsen, Babara (1993), "Brand Royalty and Lineage: Exploring New Dimensions for Research," Advances in Consumer Research, 20, 575-579.

Otnes, Cele and Tina M. Lowrey (1993), " 'Til Debt Do Us Part: The Selection and Meaning of Artifacts in the American Wedding," Advances in Consumer Research, 20, 325-329.

-------, Michelle Nelson, and Mary Ann McGrath (1995), "The Children's Birthday Party: Study of Mothers s Socialization Agents, " Advances in Consumer Research, 22, 622-627. and Linda M. Scott (1996), "Somthing Old, Something New: Exploring the Interaction Between Ritual and Advertising, "Journal of Advertising, 25(1), 33-50

Park, Cheol (1997), "Consumption in Korean Wedding Ritual: Wedding Ritual Values, Consumer Needs, and Expenditure," Journal of Family and Economic Issues, 18(2), 191-209.

Peterson, Robert A. (1994), "A Metaanalysis of Cronbach's Coefficient Alpha," Journal of Consumer Research, 21 (September), 381-391.

Pollay, Richard W. (1987), "It's the Thought That Counts: A Case Study in Xmas Excesses," Advances in Consumer Research, 14, 140-143.

Riecken, Glen and Ugur Yavas (1983), "Internal Consistency Reliability of King and Sumers' Opinion Leadership Scale: Further Evidence," Journal of Marketing Research, 20 (August), 325-326.

Rook, Dennis W. and Sidney Levy (1983), "Psychosocial Themes in Consumer Grooming Rituals," Advances in Consumer Research, 9, 329-333.

----- (1984), "Ritual Behavior and Consumer Symbolism," Advances in Consumer Research, 10, 279284.

----- (1985), "The Ritual Dimension of Consumer Behavior," Journal of Consumer Research, 14 (September), 189-199.

Ruth, Julie A. (1995), "Sad, Glad, and Mad: The Revealing Role of Emotions in Consumer Rituals, " Advances in Consumer Research, 22, 692.

Schmidt, Leigh Eric (1995), Consumer Rites, Princeton, NJ; Princeton University Press. 
Schouten, John W. (1991), "Selves in Transition: Symbolic Consumption in Personal Rites of Passage and Identity Reconstruction," Journal of Consumer Research, 17 (March), 412-425.

Sherry, Jr., John F. (1986), "Gift Giving in Anthropological Perspective," Journal of Consumer Research, 10 (September), 157-168.

Solomon, Michael R. (1983) and Punam Anand (1985), "Ritual Costumes and Status Transition: The Female Business Suit as Totemic Emblem," Advances in Consumer Research, 11,315-318.

Tetreault, Mary A. Stanfield and Robert E. Kleine III (1990), "Ritual, Ritualized Behavior and Habit: Refinements and Extensions of the Consumption Ritual Construct," Advances in Consumer Research, 17, 31-38.

Thompson, Craig J. and Elizabeth C. Hirschman (1995), "Understanding the Socialized Body: A Poststructuralist Analysis of Consumers Self-Conceptions, Body Images, and Self-Care Practices," Journal of Consumer Research, 22 (September), 139-153.

Turner, Victor (1969), The Ritual Process, Chicago: Aldine.

Van Gennep, Arnold (1908), The Rites of Passage.trans. K.S.Jun, Seoul: El-U Publishing.

Wallendorf, Melanie and Michael D. Reilly (1991), "'We Gather Together": Consumption Rituals of Thanksgiving Day," Journal of Consumer Research, 18 (June), 13-31. 